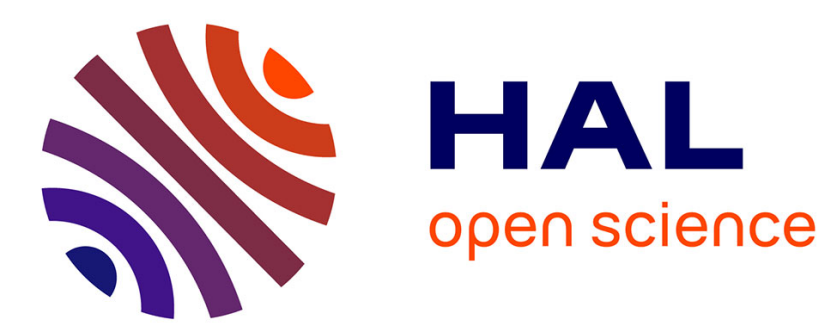

\title{
TWO-PHOTON LASER-ASSISTED REACTIONS OF Xe WITH HALOGEN CONTAINING MOLECULES
}

\author{
D. Setser, Jun. Qin
}

\section{To cite this version:}

D. Setser, Jun. Qin. TWO-PHOTON LASER-ASSISTED REACTIONS OF Xe WITH HALOGEN CONTAINING MOLECULES. Journal de Physique IV Proceedings, 1991, 01 (C7), pp.C7-579-C7-582. 10.1051/jp4:19917154 . jpa-00250829

\section{HAL Id: jpa-00250829 https://hal.science/jpa-00250829}

Submitted on 1 Jan 1991

HAL is a multi-disciplinary open access archive for the deposit and dissemination of scientific research documents, whether they are published or not. The documents may come from teaching and research institutions in France or abroad, or from public or private research centers.
L'archive ouverte pluridisciplinaire HAL, est destinée au dépôt et à la diffusion de documents scientifiques de niveau recherche, publiés ou non, émanant des établissements d'enseignement et de recherche français ou étrangers, des laboratoires publics ou privés. 


\title{
TWO-PHOTON LASER-ASSISTED REACTIONS OF Xe WITH HALOGEN CONTAINING MOLECULES $(\mathbf{1})$
}

\author{
D.W. SETSER and Jun. QIN \\ Department of Chemistry, Kansas State University, Manhattan, KS 66506, USA
}

\begin{abstract}
The two-photon, laser-assisted reactions between $\mathrm{Xe}$ (or $\mathrm{Kr}$ ) and several halogen containing molecules have been observed by focusing the output of a pulsed dye-laser into dilute gas mixtures of Xe and the reagent. The occurrence of the reaction is detected from the $\mathrm{B}-\mathrm{X}$ fluorescence of the $\mathrm{XeCl}^{*}, \mathrm{XeBr}^{*}$ and $\mathrm{XeI}^{*}$ products. Results from studies with $\mathrm{SOCl}_{2}, \mathrm{CCl}_{4}, \mathrm{CCl}_{3} \mathrm{Br}, \mathrm{CCl}_{2} \mathrm{Br}_{2}, \mathrm{Br}_{2}$ and $\mathrm{I}_{2}$ are emphasized. In some instances the utilization of laser pulses of different frequency to drive the reaction enhanced the two-photon cross section, relative to one-color experiments, because of a more favorable energy resonance with the one-photon $\mathrm{RX}^{*}$ intermediate state. Direct excitation from bound and free $\mathrm{Xe} / \mathrm{RX}$ pairs on the van der Waals potential to the ion-pair, $\mathrm{Xe}^{+} \mathbf{R X}$, reactive potential explains most aspects of these laser-assisted reactions. One application of these laser-assisted reactions is as a very rapid generation source for $\mathrm{XeCl}^{*}$ and $\mathrm{KrF}^{*}$ molecules in order to study their quenching and relaxation kinetics.
\end{abstract}

The two-photon, photo-excitation of $\mathrm{Xe}^{1-5}$ and halogen $(\mathrm{X})$ containing molecules $(\mathrm{RX})$ to the reactive ion-pair potential, $\mathrm{V}\left(\mathrm{Xe}^{+} ; \mathrm{RX}^{-}\right)$, has now been documented with more than 15 molecules. Upon reaching the ion-pair potential, the expected bimolecular reaction occurs with formation of $\mathrm{XeX}(\mathrm{B}, \mathrm{C})+\mathbf{R}$. In addition to the Xe reactions, the laser-assisted reactions (LAR) between $\mathrm{Kr}$ and halogen molecules also are possible and two examples are $\mathrm{Kr} / \mathrm{F}_{2}$ and $\mathrm{Kr} / \mathrm{CCl}_{4}{ }^{2}$ The $\mathrm{LAR}$ of $\mathrm{Kr} / \mathrm{RX}$ requires shorter wavelength because the laser ionization energy of $\mathrm{Kr}$ raises the $\mathrm{V}\left(\mathrm{Kr}^{+} ; \mathrm{RX}^{-}\right)$relative to $\mathrm{V}\left(\mathrm{Xe}^{+} ; \mathrm{RX}\right)$. The two-photon cross section is greatly enhanced by an intermediate $\mathrm{RX}^{*}$ resonance state and in general the LAR of Xe/RX requires a $\mathrm{RX}^{*}$ state. ${ }^{3}$ For this reason two-color, two-photon LAR is much easier to accomplish, unless the intermediate state fortuitously lies midway between the ground van der Walls potential and the reactive ion pair potential. A summary of the systems that have been studied in our laboratory for dilute gas conditions is given in Table $\mathrm{I}^{2,3}$

The single color, two-photon $\mathrm{LAR}$ for $\mathrm{Xe} / \mathrm{Cl}_{2}$ and $\mathrm{Xe} / \mathrm{CIF}$ is very facile in dilute gases (10-50 Torr of $\mathrm{Xe}$ and 1-3 Torr of $\mathrm{Cl}_{2}$ ) for laser pulses of $1 \mathrm{~mJ}$ focused with a $0.5 \mathrm{~m}$ lens. ${ }^{1,4}$ The excitation spectra are unstructured bands with half-widths of $\sim 0.3 \mathrm{eV}$. However, the single color LAR for $\mathrm{Xe} / \mathrm{Br}_{2}$ and $\mathrm{Xe} / \mathrm{I}_{2}$ is very difficult to observe, even though the $\mathrm{V}\left(\mathrm{Xe}^{+} ; \mathrm{Br}_{2}^{-}\right)$and $\mathrm{V}\left(\mathrm{Xe}^{+} ; \mathrm{I}_{2}\right)$ ion-pair potentials are known. ${ }^{1,4}$ This puzzle has been resolved by the use of two-color, two-photon excitation. ${ }^{3}$ If one laser is tuned to the $\mathrm{Br}_{2}\left(\mathrm{X}-\mathrm{A}\left({ }^{1} \Pi_{v}\right)\right.$ ) absorption band in the 440-510 nm range and the frequency of the second laser adjusted to match the energy required to reach $V\left(\mathrm{Xe}^{+} ; \mathrm{Br}_{2}{ }^{-}\right), \mathrm{LAR}$ giving $\operatorname{XeBr}(B, C)$ is easily observed. In practice the same dye laser was used for the two colors and the fundamental plus the doubled outputs of the laser were focused into the laser cell. The same strategy was used for $\mathrm{Xe} / \mathrm{I}_{2}$, and LAR giving $\mathrm{Xel}(\mathrm{B}, \mathrm{C})$ was observed for excitation at $455.0+227.5$ $\mathrm{nm}^{3}{ }^{3}$ The maximum in the excitation spectra for Xe with diatomic halogens is fixed by the vertical electron affinity of $X_{2}$ and the position of the minimum on the van der Waals potential. The width

(1) This work was supported by the U.S. National Science Foundation. 
TABLE 1 SUMMARY OF LASER ASSISTED REACTIONS

\begin{tabular}{|c|c|c|c|c|c|}
\hline Systems & One-color & Two-color & Systems & One-color & Two-color \\
\hline $\mathrm{Xe} / \mathrm{Cl}_{2}$ & yes & & $\mathrm{Xe} / \mathrm{CClHBr}_{2}$ & yes & yes \\
\hline $\mathrm{Xe} / \mathrm{ClF}$ & yes & & $\mathrm{Xe} / \mathrm{CBr}_{4}$ & yes & yes \\
\hline $\mathrm{Xe} / \mathrm{F}_{\mathrm{z}}$ & yes & & $\mathrm{Xe} / \mathrm{CHBr}_{3}$ & yes & yes \\
\hline $\mathrm{Xe} / \mathrm{Br}_{2}$ & no & yes & $\mathrm{Xe} / \mathrm{CFBr}_{3}$ & yes & yes \\
\hline $\mathrm{Xe} / \mathrm{I}_{2}$ & no & yes & $\mathrm{Xe} / \mathrm{CH}_{2} \mathrm{I}_{2}$ & yes. & yes \\
\hline $\mathrm{Xe} / \mathrm{SOCl}_{2}$ & yes & & $\mathrm{Xe} / \mathrm{CH}_{3} \mathrm{I}$ & weak & \\
\hline $\mathrm{Xe} / \mathrm{CCl}_{4}$ & yes & yes & $\mathrm{Xe} / \mathrm{CF}_{3} \mathrm{I}$ & weak & \\
\hline $\mathrm{Xe} / \mathrm{CCl}_{3} \mathrm{Br}$ & yes & yes & $\mathbf{K} \mathbf{r} / \mathbf{F}_{\mathbf{2}}$ & yes & \\
\hline $\mathrm{Xe} / \mathrm{CCl}_{2} \mathrm{Br}_{2}$ & yes & yes & $\mathrm{Kr} / \mathrm{CCl}_{4}$ & yes & \\
\hline
\end{tabular}

of a spectrum is largely determined by the gradient of the potential in the $R(X-X)$ coordinate. Thus, the excitation spectra for LAR provide a way to probe the properties of the radical anion.

The $\mathrm{SOCl}_{2}, \mathrm{CCl}_{4}, \mathrm{CCl}_{3} \mathrm{Br}$, and $\mathrm{CCl}_{2} \mathrm{Br}_{2}$ molecules have one-photon intermediate states with absorption beginning about $280 \mathrm{~nm}$. One-photon LAR is observed in each case for mixtures of $\geq$ 10 Torr Xe and $\geq 2$ Torr of reagent. ${ }^{3}$ The two-color experiments gave somewhat higher product yields than one-color experiments, in part because of higher laser pulse energy for the fundamental dye laser pulse, but also the intrinsic cross section seems larger. ${ }^{3}$ The one-color excitation spectra for $\mathrm{SOCl}_{2}$ and $\mathrm{CCl}_{4}$ are shown in Figure 1. These are shifted to shorter wavelengths than for $\mathrm{Cl}_{2}$ or CIF because (i) The $\mathrm{Re}_{\mathrm{e}}\left(\mathrm{Xe}-\mathrm{CCl}_{4}\right)$ is larger in the lower state than for $\mathrm{R}_{\mathrm{e}}\left(\mathrm{Xe}_{\mathrm{e}} \mathrm{Cl}_{2}\right)$, and (ii) The $\mathrm{EA}\left(\mathrm{CCl}_{4}\right)$ is smaller than for $\mathrm{Cl}_{2}$. The increased breadth and apparent broad structure in the excitation spectra probably reflect the availability of electronically excited radical anion states, as well as a larger range of Franck-Condon factors for the polyatomic systems.

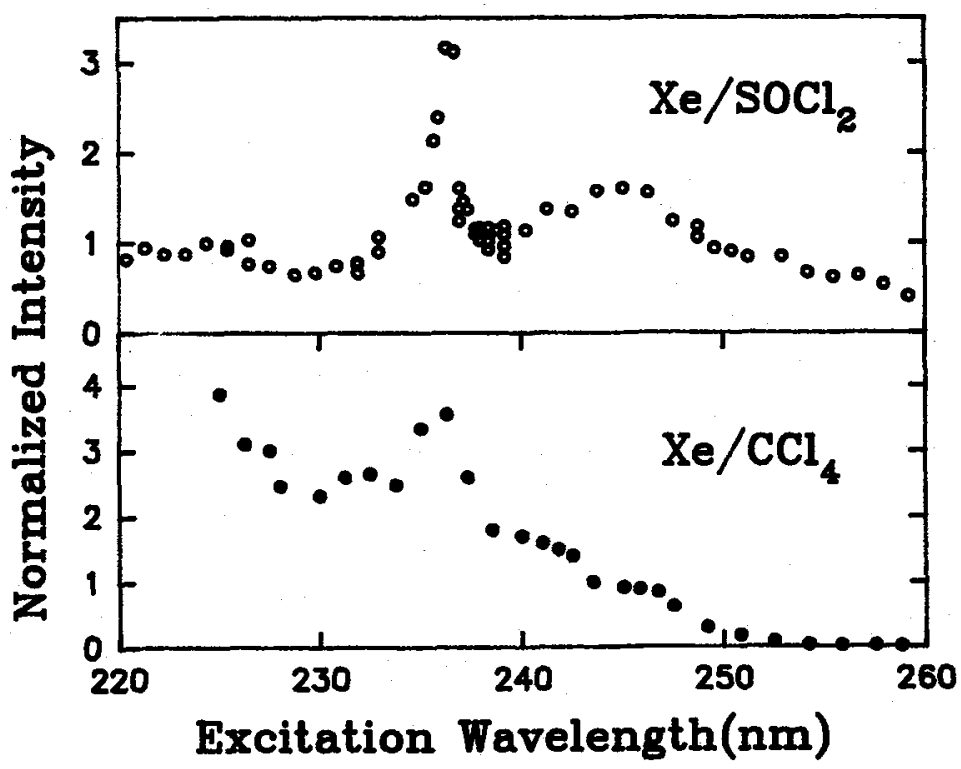

Figure 1. The two-photon, single-color excitation spectra for the $\mathrm{LAR}$ of $\mathrm{CCl}_{4}$ and $\mathrm{SOCl}_{2}$.

The $\mathrm{CCl}_{3} \mathrm{Br}$ and $\mathrm{CCl}_{2} \mathrm{Br}_{2}$ reactions are especially interesting because both $\mathrm{XeCl}(\mathrm{B}, \mathrm{C})$ and $\mathrm{XeBr}(\mathrm{B}, \mathrm{C})$ can be formed. The full collision of $\mathrm{Xe}\left(6 \mathrm{~s},{ }^{3} \mathrm{P}_{2}\right)$ with $\mathrm{CCl}_{2} \mathrm{Br}_{2}$ and $\mathrm{CCl}_{3} \mathrm{Br}$ favors $\mathrm{XeBr}(\mathrm{B}, \mathrm{C})$ by ratios of $\sim 5 / 1$ and $2 / 1$, respectively. This is the expected result because the ground state of $\mathrm{CCl}_{3} \mathrm{Br}^{-}$has the extra electron in the $\mathrm{C}-\mathrm{Br}$ antibonding orbital. ${ }^{6.7}$ Since $\mathrm{XeBr}(\mathrm{B}, \mathrm{C})+$ $\mathrm{CCl}_{2} \mathrm{Br}$ is the most exoergic channel (by $\sim 0.3 \mathrm{eV}$ ), the $\mathrm{XeBr}(\mathrm{B}, \mathrm{C})$ channel correlates directly to the 
ground state of the radical anion. The $\mathrm{XeCl}(\mathrm{B}, \mathrm{C})+\mathrm{CBr}_{2} \mathrm{Cl}$ channel correlates to an excited radical anion state. The electron attachment data ${ }^{6}$ show that two excited $\mathrm{CCl}_{3} \mathrm{Br}^{-}$states exist and these are expected to have more electron density on the $\mathrm{Cl}$ atoms. The product fluorescence spectrum from a one-color $(253 \mathrm{~nm})$ LAR experiment is shown in Figure $2 \mathrm{~A}$; the $\mathrm{XeCl}(\mathrm{B}, \mathrm{C})$ product is strongly favored, in contrast to the $\mathrm{Xe}(6 \mathrm{~s})$ reactions. These data provide a clear demonstration that controlling the initial conditions of a bimolecular reaction can greatly affect the end result, not only for energy distributions, but also the chemical product branching. The LAR results for $\mathrm{CCl}_{2} \mathrm{Br}_{2}$, not shown here, are very similar to those for $\mathrm{CCl}_{3} \mathrm{Br}$.

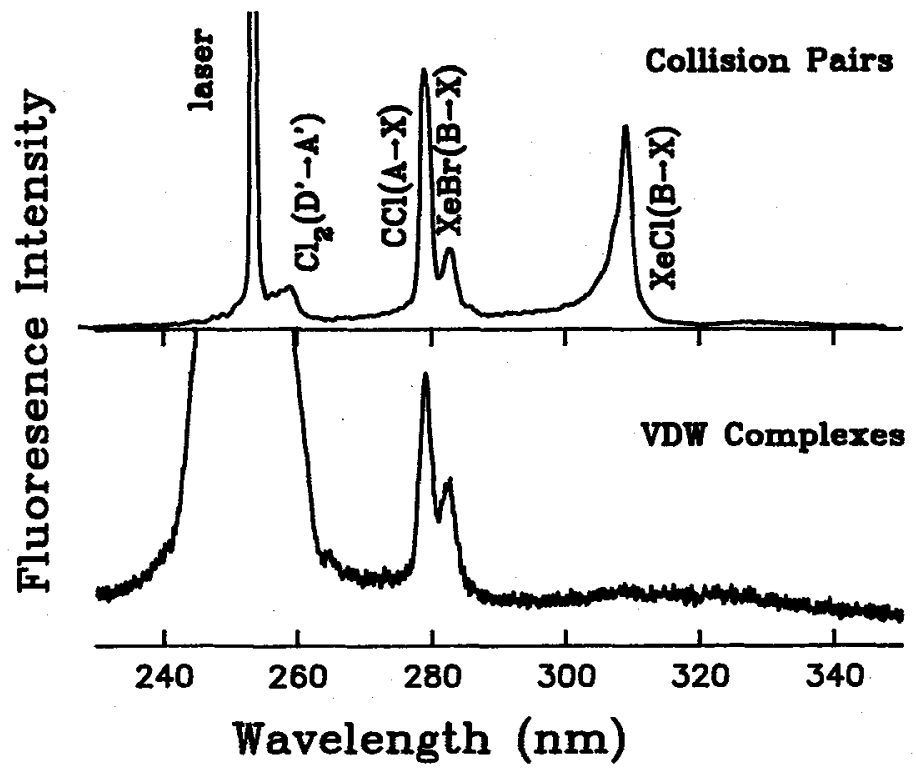

Figure 2. Product fluorescence spectra from $\mathrm{LAR}$ of $\mathrm{Xe}$ with $\mathrm{CCl}_{3} \mathrm{Br}$ in a dilute gas mixture and from van der Waals molecules formed in a free-jet expansion.

The correct explanation of the difference between the full collision and LAR is not so obvious. One possibility is that the $\mathrm{XeCl}(\mathrm{B}, \mathrm{C})$ channel is partly blocked in the full collision because the approach of $\mathrm{Xe}(6 \mathrm{~s})$ to the chlorine end of the molecule results in excitation-transfer quenching before the curve crossing region between $\left(\mathrm{Xe}^{+} ; \mathrm{Cl}^{-}-\mathrm{CCl}_{2} \mathrm{Br}\right)^{*}$ is reached. In contrast, photo-excitation can directly transport the collision pair at the $\mathrm{R}\left(\mathrm{Xe}-\mathrm{CCl}_{3} \mathrm{Br}\right)$ in the van der Waals molecule to the $\mathrm{Xe}^{+} ; \mathrm{Cl}^{-}-\mathrm{CBrCl}_{2}$ configuration. Apparently, the one-photon $\mathrm{CCl}_{3} \mathrm{Br}^{*}$ intermediate facilitates the charge transfer to the excited radical-anion state. From a statistical point of view, the Xe will have a higher probability for being close to $\mathrm{a} \mathrm{Cl}$ atom than to the $\mathrm{Br}$ atom in the $300 \mathrm{~K}$ dilute gas. The surprising result is that the $\mathrm{V}\left(\mathrm{Xe}^{+}-\mathrm{Cl}^{-} \mathrm{CBrCl}_{2}\right)$ configuration, which correlates to an excited radical anion state, is as low in energy as implied by the two-color experiment. In the presence of $\mathrm{Xe}^{+}$, the ground and excited potentials for the radical anion must be close in energy.

Figure 2B illustrates the dramatic reversal of product channels for LAR of bound van der Waals molecules $\left(\mathrm{Xe}^{\circ} \mathrm{BrCCl}_{3}\right)$ formed in a free jet. In this experiment only $\mathrm{XeBr}(\mathrm{B})$ was observed. The $\mathrm{CCl}(\mathrm{A}-\mathrm{X})$ emission is a consequence of multiphoton dissociation of $\mathrm{CCl}_{3} \mathrm{Br}$. These free-jet experiments are preliminary and they must be confirmed. If they prove to be true, they imply that the bound van der Waals molecule has the $\mathrm{Xe} \bullet \mathrm{Br}-\mathrm{CCl}_{3}$ structure. Excitation from this configuration then can lead only to $\mathrm{Xe}^{+} ; \mathrm{Br}^{-}-\mathrm{CCl}_{3}$, which yields $\mathrm{XeBr}(\mathrm{B}, \mathrm{C})$. If this is true, the two-color LAR excitation spectra for $\mathrm{Xe}$ with $\mathrm{CCl}_{3} \mathrm{Br}$ should be different for the bound molecules vs. the free molecules in a $300 \mathrm{~K}$ dilute mixture because the final $\mathrm{V}\left(\mathrm{Xe}^{+} ; \mathrm{RX}^{-}\right)$states are different.

The $\mathrm{XeCl}^{*} / \mathrm{XeBr}^{*}$ product branching ratio from $\mathrm{LAR} \mathrm{of} \mathrm{CCl}_{3} \mathrm{Br}$ (and $\mathrm{CCl}_{2} \mathrm{Br}_{2}$ ) in dilute gases is very wavelength dependent. This is demonstrated by the excitation spectra for the $\mathrm{XeCl}(\mathrm{B}, \mathrm{C})$ and 
$\operatorname{XeBr}(\mathrm{B}, \mathrm{C})$ channels in Figure 3. The change in the product ratio with wavelength is a consequence of photo-excitation to two different electronically excited $\mathrm{CCl}_{3} \mathrm{Br}^{-}$states. This interpretation is supported by the energy dependence of the dissociative electron attachment cross sections. ${ }^{6,7}$

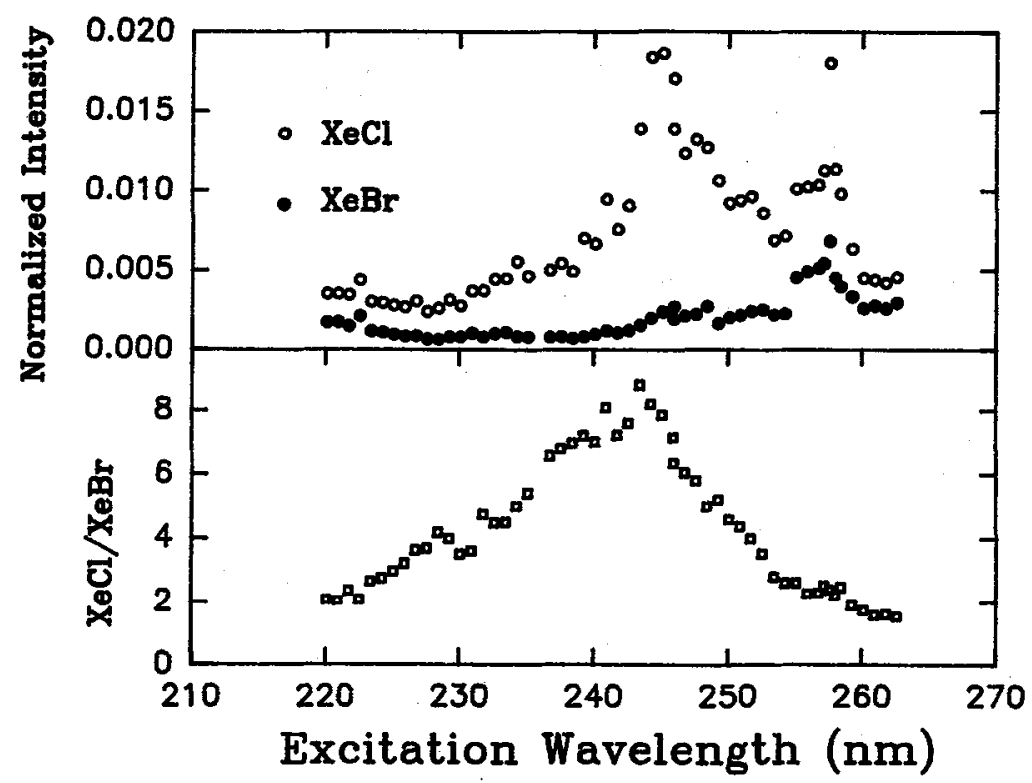

Figure 3. Two-photon, single-color excitation spectra for $\mathrm{XeCl}^{*}$ and $\mathrm{XeBr}^{*}$ formation from $\mathrm{Xe}\left(30\right.$ Torr) with $\mathrm{CCl}_{3} \mathrm{Br}$ ( 2 Torr). The ratio is plotted in the second panel.

In addition to providing data that illuminate the dynamics of reactions on the $\mathrm{V}\left(\mathrm{Xe}^{+} ; \mathrm{RX}^{-}\right)$ potential surface, the LAR generate $\mathrm{XeX}(\mathrm{B}, \mathrm{C})$ molecules on the same time scale as the laser pulse. This rapid generation in a clean controllable environment permits the study of quenching kinetics of $\mathrm{XeCl}(\mathrm{B}, \mathrm{C})^{8}$ and $\mathrm{KrF}(\mathrm{B}, \mathrm{C}) .^{9}$

\section{REFERENCES}

(1) KU, J.K.; INOUE, G.; SETSER, D.W. J. Phys. Chem. 1983, 87, 1989, and in

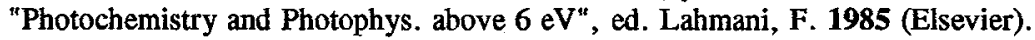

(2) NELSON, T.O.; SETSER, D.W. Chem. Phys. Lett. 1990, 170, 430, and J. Phys. Chem. 1991, 95, in press.

(3) QIN, J.; SETSER, D.W. Chem. Phys. Lett. 1991, in press.

(4) JOUVET, C.; BOIVINEAU, M.; DUVAL, M.C.; SOEP, B. J. Chem. Phys. 1987, 91, 5416.

(5) BoIVINEAU, M.; LeCAlVE, J.; CASTEX, M.C.; JOUVET, C. J. Chem. Phys. 1986, 84, 4712.

(6) OLTHOFF, J.K.; MOORE, J.H.; TOSSELL, J.A. J. Chem. Phys. 1986, 85, 249.

(7) ORIENT, O.J.; CHUTJIAN, A.; CROMPTON, R.U.; CHEUNG, B. Phys. Rev. A 1989, $\underline{39}, 4496$.

(8) QUINONES, E.; YU, Y.C.; LO, G.; SETSER, D.W. J. Chem. Phys. 1990, 93333.

(9) GADOMSKI, W.; XU, J.; SETSER, D.W. J. Chem. Phys. to be published. 